\title{
Research on Foreign Trade Development Strategies of Inner Mongolia
}

\author{
Xiao-Ping Wang ${ }^{1,2, a,{ }^{*}}$ \\ ${ }^{1}$ School of Economics, Wuhan University of Technology, Wuhan, P. R. China \\ ${ }^{2}$ Business College, Inner Mongolia University of Finance and Economics, Hohhot, P. R. China \\ asophiawang188@126.com \\ ${ }^{*}$ Corresponding author
}

Keyword: Inner Mongolia, Foreign trade, development, Development strategy

\begin{abstract}
There exists different problems in foreign trade of Inner Mongolia at different times for nearly half a century, therefore, it is particularly important to analyze these problems especially in a critical period when structural adjustment, transformation and upgrading is on hand. Grounded on the achievements analysis of foreign trade development in Inner Mongolia, the main problems existing in the development are analyzed and further development strategies are proposed in this paper.
\end{abstract}

\section{Introduction}

Located in the less developed western border region, Inner Mongolia took its Regional advantages, resources advantages and policy advantages such as border opening policy, the western development strategy, revitalizing the northeast old industrial base strategy and opening up to the North policy conferred and implemented by the State, actively participated in the competition and cooperation of international market, Paid equal attention to "bringing in" and "going out" strategy and achieved remarkable results in the development of foreign trade.

\section{Achievements of foreign trade development of Inner Mongolia}

a. Foreign trade scale is expanding. Foreign trade development in Inner Mongolia's began in 1947, but the rapid development appeared after the reform and opening up. During the 30 years, the scale of foreign trade development continued to expand from $\$ 15.52$ million in 1978 , to \$ 11.257 billion in 2012, an increase of approximately 724 times in 34 years.

b. Import and export commodity structure is optimizing. Before the reform and opening up, a small number of commodities are exported from Inner Mongolia, among which more than $70 \%$ are grain and oil, native products and livestock, plus a small amount of ore sand, industrial products and herbs. 30 years since the reform and opening up, export commodities of Inner Mongolia have exceeded 700 kinds, import and export commodity structure has also been optimized.

c. Service trade development like transport, tourism, engineering contracting and etc. take shape. In recent years, Inner Mongolia strove to develop the port cargo and passenger transport, foreign project contracting and border tourism, as a result, freight and passenger volume increased year by year, border tourism also developed rapidly.

d. Private enterprises have become the main force of the region's foreign trade. Since the reform and opening up, China's various types of enterprises continue to grow, especially the private enterprises which have played an increasingly important role in Inner Mongolia's foreign trade.

e. General trade, border trade have become the main form of foreign trade development in this 
region. The large proportion general trade and border trade take in Inner Mongolia's foreign trade plays an important role in promoting economic growth, industrial upgrading and technological innovation in the region.

\section{The main problems exist in Inner Mongolia's foreign trade}

The reform and opening up witnessed the rapid development of foreign trade in Inner Mongolia, but compared with coastal provinces and other open border provinces, there is a large gap, mainly manifested in the following aspects:

a. There are still large gaps in opening levels compared with other provinces. Import and export volume is small, ranked poorly in the whole nation. Use of foreign capital is limited. The level and scale of economic cooperation with foreign countries is small.

b. Inadequate market development, real diversified market system has not been established. Although the region has more than 160 trade partners, the main partners are still in traditional markets. In 2012, the region's total trade was $\$ 11.256$ billion, of which $\$ 2.723$ billion was with Russia, \$ 3.26 billion was with Mongolia, the two combined for a total of $\$ 5.983$ billion, accounting for $53.2 \%$.

c. Trade structure needs to be further optimized. The problems of low level in trade structure are prominent and manifested in the following two aspects: Similar to China's overall trade structure, goods trade is the region's major development; the internal structure of trade is unreasonable. Though export of high-tech and electromechanical products grew rapidly, it still took a low proportion of the country's total trade. Rresource products become major imported goods in the region. Resource and energy products like coal, logs, lumber, and copper concentrate, crude oil, fertilizers, organic chemicals, iron ore, wood pulp, and dairy raw materials become the leading imported products.

d. Prominent trade imbalance. Import and export are imbalance. There are obvious regional characteristics in foreign trade development of prefectural-level cities in Inner Mongolia. Along with the active implementation of opening-up-to-the-North policy, the port city's trade development tends to be good.

e. Lack of large-scaled international competitive enterprises. By the end of 2012, there has been 6821 import and export enterprises registered for record in the region, but all were small-scaled and poor in performance. Currently, there are 51 enterprises with their export scale exceeding ten million, and 118 enterprises with import scale more than ten million.

f. Import and export base construction lags behind, public service platform capabilities are weak. According to the actual trade development situation, after years of development, textile, agricultural and livestock products, industrial products, etc., especially cashmere products, nonferrous metals, and rare earths have become competitive exports, but there is no scale advantage, for competitive exports and backbone enterprises are rare in the international market. Export bases construction lags behind, lack of development potential. Most resources from Russia and Mongolia were imported into the country through ports in the region, while deepen processing of imported resources are not enough in the region.

\section{Suggestions on further development of foreign trade strategies in Inner Mongolia}

\section{To study and implement policies and measures stabilizing foreign trade growth}

Continue to study and implement the State Council's polices and measures favorable to steady growth of foreign trade, strengthen coordination and cooperation between various departments, and 
join forces to help enterprises reduce export costs and improve trade environment.

Give tax incentives or relief to projects that are in line with national industrial policy and are significantly beneficial to transformation and upgrading of industrial and trade structure. Encourage domestic commercial banks to conduct export credit business and improve service levels in accordance with the principles of controllable risks and sustainable business. Give full play to the role of state policy bank's support for foreign trade development, expand financing guarantee institutions business towards small and medium-size enterprises (SMEs) and increase support for SMEs export credit.

\section{Continuing to promote market diversification strategy, to build an all-round opening pattern in the region}

In order to expand the directional market, firstly, to further expand traditional markets with Russia and Mongolia. Inner Mongolia is similar to Russia and Mongolia in particular in history, and cultural customs, etc. They are all abundant with resources, and have the potential and convenience to conduct industrial cooperation. At present, the region should develop economic and trade cooperation with Russia and Mongolia on the basis of mutual benefit and interest. Secondly, to expand markets with developed countries or regions like the United States, European Union, Japan and etc. Because of the different resource endowments of the region and these developed countries, there exists economic complementarity. Hence, the region can give full play to its comparative advantages, exporting cashmere products, green agricultural and livestock products, introducing technology, capital and management experience from developed countries, so as to enhance the international competitiveness of its export products. Thirdly, focus on the development of emerging markets and developing country markets with deep development potential and huge markets capacity like Middle East, Central Asia, South America, Africa, and Eastern Europe and so on. To enhance mutual understanding and promote greater trade development through various forms of economic and trade cooperation and exchanges.

\section{Speeding up industrial restructuring, transforming foreign trade development mode}

Based on the basic conditions for industrial development in the region, it should accelerate the introduction of advanced applicable technology and equipment, conduct technological transformation for traditional industries, upgrade technological levels of the industries, increase added value and technology content of products, make traditional products the backbone, take export of high-tech and electromechanical products as lead, give full play to high-tech industries and to expand exports effects. Improve relevant supporting policies and measures to increase export support for electromechanical and high-tech products. Encourage establishment of various research and development platforms in industry cluster districts and export bases to help enterprises develop generic and key technologies with independent intellectual property rights, and expand export of own-brand products. In particular to support the development of industries with regional advantages and characteristics like new rare earth materials, coal chemical, new energy, equipment manufacturing, new materials, bio-engineering, green agricultural and livestock products, metallurgical materials, low-carbon energy-saving and environmental protection industries.

Enhance the overall level of traditional bulk exports. Promote traditional industrial restructuring, strengthen regulation and guidance, encourage the development of new technology and products of high-tech, high added value, low consumption and low emissions, extend the industrial chain, and form new export growth. Improve early warning and monitoring for exports, ensure stable export growth of labor-intensive products like agricultural products, light industrial products, and textiles, and stabilize domestic employment. Accelerate the transformation and upgrading of traditional 
export industries, drive the industry and enterprises to develop international certification and quality inspections, etc., and improve design and development capabilities.

\section{Intensifying efforts to open the north, enhance economic and trade cooperation with Russia and Mongolia}

On the basis of mutual benefit, the region continues to expand economic and trade cooperation with Mongolia and Russia, deepen the level of cooperation, and vigorously promote exchanges and cooperation between the adjacent areas. Strengthen and standardize the construction and management of border economic and trade cooperation zones and frontier trade areas for border inhabitants. Actively support the construction and development of Manchuria national key opening-and-development pilot area, Erlianhot key reform-and-opening up pilot area, and Bayannao'er processing pilot area of outside resources. Support and encourage powerful enterprises to invest in Russia and Mongolia to develop assembly production. Back up enterprises to establish marketing network, marketing service center and technical service center in Russia and Mongolia. In favor of enterprises to conduct contracted projects and labor cooperation in Russia and Mongolia, focusing on strengthening cooperation with Russia and Mongolia in development of mineral resources, wood processing, farming, food processing etc. Cultivate internationally competitive large-project-contracting enterprises so as to promote export of complete sets of equipment.

\section{Accelerating construction of foreign trade base, trade platforms and overseas marketing network}

Accelerate the construction of a number of export bases relying on various development zones, industrial zones and Industry cluster districts according to national and regional industrial policy and planning. Build processing bases of coal chemicals, rare earth, metallurgical materials, photovoltaic materials, equipment manufacturing, heavy vehicles, textiles and clothing, and agricultural and livestock products. Focus on the construction of export bases with strong radiation and leading role in export such as high-tech products, electromechanical products and specialty products etc. Cultivate and construct national and regional foreign trade transformation and upgrading demonstration bases, so as to guarantee the amount and improve the quality of foreign trade exports of the region. Actively seek national policy and financial support and making full use of the national and regional special funds related to foreign trade development. Encourage independent innovation, technological innovation and brand development of enterprises in export bases, increase efforts to support public service platforms in theses bases. Pay great attention to the construction of imported bases, nurture and build processing-upon-landing bases of imported resources in ports and pan-port areas where imported resources and energy are intensive, improve the added value of imported resources, and get out of the dilemma of lack industry support and development potential.

Encourage and support domestic enterprises to participate in the exhibitions, especially hold and participate in exhibitions in emerging markets, register trademarks, conduct quality certification, expand foreign propaganda and enhance foreign trade development potential. Organize qualified enterprises to actively participate in the activities of developing emerging markets hosted by Ministry of Commerce. Actively guide and support enterprises to develop foreign trade and enlarge market share with help of the third-party e-commerce platforms recommended by Ministry of Commerce. Cultivate and build specialized foreign trade market, emphasizing the construction of integrated domestic and foreign trade markets in border areas such as Erlianhot, Manchuria, Ejinaqi Ceke port economic and trade zone. 


\section{Establishing a unified early warning mechanism of industrial safety and maintenance as well as trade remedy}

Actively respond to the increasingly severe international trade protectionism and frequent international trade friction, establish a unified early warning mechanism of industrial safety and maintenance as well as trade remedy led by the local government, guided by local commerce department, and participated in by various departments and industries as soon as possible. Local governments should actively support the establishment of networks to maintain industrial security and trade remedies so as to help enterprises prepare for and deal with trade friction. Carry out regular surveys and studies on trade and investment, monitor key industries and bulk import and export goods, grasp the import and export changes of goods and industries timely. Push enterprises to actively participate in and deal with international trade friction cases, and enhance their abilities to avoid risks and safeguard legitimate rights and interests. Continue to cultivate and train government and enterprise personnel the knowledge of maintaining industrial security and trade remedy.

\section{Accelerating economic and trade talent cultivation, developing talent resources advantages}

Innovate market-oriented talent management system and service system, establish multi-level foreign trade personnel, and create a favorable development environment for foreign trade professionals. To further strengthen business personnel training of foreign trade enterprises, cultivate applied talents of certain industries or professions in designated universities or colleges in the region so as to improve their professional proficiency as soon as possible. Attach great importance to foreign trade vocational education, increase government funding, and extensively absorb diversified funds to speed up the pace of specialized talents cultivation. To actively introduce high-quality talents of foreign trade, especially introducing multilateral and bilateral foreign trade negotiators, legal professionals familiar with international regulations and special talents familiar with local trade development needs.

\section{Summary}

This paper analyze the foreign trade development strategies of Inner Mongolia, first, we study the achievements of foreign trade development of Inner Mongolia, and then, further analyze the main problems exist in Inner Mongolia's foreign trade. Based on the above, the suggestions on further development of foreign trade strategies in Inner Mongolia, including study and implement policies and measures stabilizing foreign trade growth; continuing to promote market diversification strategy, to build an all-round opening pattern in the region, and so on.

\section{References}

[1] Jian Li, Realizing Balanced, Coordinated and Sustainable Growth [J], Intertrade, 2011(2). (In Chinese)

[2] Guoqing Zhang, Further Improvement of Opening Level [J], Intertrade, 2011(3). (In Chinese)

[3] Li Zhang, Constructing Theoretical System of Transforming Foreign Trade Development Mode, Intertrad [J], 2012(5). (In Chinese)

[4] Shouwen Wang, Transformation and Promotion of Balanced and Stable Foreign Trade 
Development, Intertrade [J], 2012(1). (In Chinese) 